九州大学学術情報リポジトリ

Kyushu University Institutional Repository

\title{
Investigating energy efficient air-conditioning options for agricultural and livestock applications
}

Sultan, Muhammad

Laboratory for Energy and Env. Engineering Research Department of Agricultural Engineering Bahauddin Zakariya University : Assistant Professor

https://doi.org/10.5109/4102453

出版情報 : Proceedings of International Exchange and Innovation Conference on Engineering \& Sciences (IEICES). 6, pp. 21-22, 2020-10-22. Interdisciplinary Graduate School of Engineering Sciences, Kyushu University バージョン:

権利関係 : 


\section{Keynote Speakers}

\section{Muhammad Sultan}

Assistant Professor

Laboratory for Energy and Env. Engineering Research

Department of Agricultural Engineering

Bahauddin Zakariya University, Pakistan

Emailः.muhammadsultan@bzu.edu.pk ; sultan@kyudai.jp

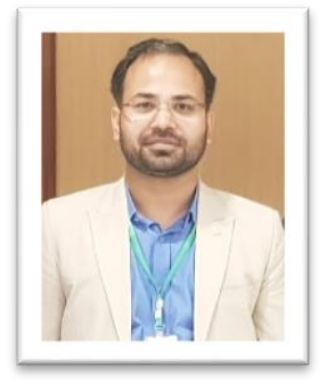

\section{Short Biography}

Muhammad Sultan obtained his Ph.D. (2015) and Postdoctoral studies (2017), respectively, in Energy \& Environmental Engineering from Kyushu University (Japan). He also did Postdoctoral studies (2019) in Mechatronic Systems Engineering at Simon Fraser University (Canada). He received his Master's in Environmental Engineering (2010) and Bachelor in Agricultural Engineering (2008) with distinctions, from the University of Agriculture, Faisalabad. Currently, he is working as Assistant Professor at Bahauddin Zakariya University, Pakistan. He is also serving as Regional Editor for the Evergreen Journal of Kyushu University. He has authored/co-authored 100+ journal and conference articles. He has published 2 book chapters and edited/co-edited 2 books. His research keywords include HVAC, desiccant air-conditioning, evaporative cooling, adsorption cooling, energy recovery ventilator, adsorption heat pump, Maisotsenko cycle (M-cycle), wastewater, and agriculture and livestock applications. 


\title{
Investigating energy-efficient air-conditioning options for agricultural and livestock applications
}

\begin{abstract}
For any nation, primary sources of energy consumption are involved in heating, cooling, humidification, dehumidification, ventilation and/or air-conditioning (HVAC), which may be required for various human/non-human applications. Usually developing countries are facing extreme energy shortage, therefore, low-cost and energy-efficient HVAC systems are principally needed worldwide. The low-cost HVAC systems are required not only for humans' thermal comfort but also for various agriculture and livestock applications. It includes (but not limited to) greenhouse dehumidification, livestock (animal) air-conditioning, poultry shed air-conditioning, fruits \& vegetable storage, grains \& dry fruit storage, storage of hides, tannery air-conditioning, industrial processes air-conditioning, ceiling \& structures for agriculture etc.

In this regard, various innovative cooling and air-conditioning technologies have been introduced worldwide. Consequently, in this talk, evaporative cooling and adsorptionbased HVAC technologies are explored. These technologies are environmentally safe and can be simply operated by water or low-grade waste heat. The low-grade waste heat can be supplied economically by many ways e.g. solar thermal energy, natural coal, biogas and/or biomass etc. From the prospective of evaporative cooling, the speech focuses on Maisotsenko cycle (M-cycle) based evaporative cooling conception in comparison with conventional direct and indirect evaporative cooling. While adsorption cooling and desiccant air-conditioning systems are focused from the prospective of thermally driven systems. Importance of selection of refrigerant and adsorbent/desiccant is also highlighted. Based on geographic and climatic conditions of countries, role of temporal and spatial variation for the development of sustainable HVAC system is addressed accordingly.
\end{abstract}

Keywords: Evaporative cooling; adsorption cooling; desiccant air-conditioning; Maisotsenko-cycle; sustainability; agriculture. 